\title{
Mekanisme Penuaan Kulit sebagai Dasar Pencegahan dan Pengobatan Kulit Menua
}

\author{
Shannaz N. Yusharyahya \\ Departemen Dermatovenereologi \\ Rumah Sakit dr. Cipto Mangunkusumo - Fakultas Kedokteran Universitas Indonesia \\ Penulis korespondensi: nadiayusharyahya@yahoo.com \\ Diterima 28 November 2020; Disetujui 19 Juli 2021 \\ https://doi.org/10.23886/ejki.9.49.150
}

\begin{abstract}
Abstrak
Seiring dengan meningkatnya populasi geriatri di Indonesia, masalah penuaan kulit juga turut meningkat. Pada populasi tersebut terjadi berbagai perubahan kulit sehingga kelainan yang ditimbulkan juga berbeda. Stres oksidatif merupakan mekanisme yang diduga kuat sebagai penyebab utama penuaan kulit. Penuaan kulit merupakan proses kompleks yang melibatkan faktor intrinsik dan ekstrinsik. Faktor intrinsik yang berperan adalah genetik, metabolisme sel, dan perubahan hormonal. Selain itu, terdapat faktor ekstrinsik seperti radiasi ultraviolet, inframerah, dan karsinogen lingkungan yang turut berperan pada penuaan kulit. Kedua faktor tersebut menyebabkan perubahan di seluruh lapisan kulit. Untuk mengatasi penuaan kulit, kini telah tersedia berbagai modalitas terapi, namun untuk menentukan terapi yang paling sesuai perlu diketahui fisiologi kulit menua, mekanisme penuaan kulit, dan manifestasi kelainan klinis kulit menua. Secara fisiologi terjadi perubahan permeabilitas, biokimia, vaskularisasi, termoregulasi, respons terhadap iritan, respons imunitas, kapasitas regenerasi, respons terhadap cedera, persepsi neurosensori dan pada tingkat genom. Jumlah sel epidermal dan laju pergantian epidermal menurun sedangkan di adneksa terjadi penurunan jumlah kelenjar sebasea yang mengakibatkan kulit kering dan mudah pecah. Penurunan jumlah melanosit menyebabkan warna rambut menjadi abu-abu keputihan dan muncul pigmentasi atipik di kulit. Folikel rambut kurang aktif sehingga meningkatkan kerontokan dan kebotakan. Di lapisan basal ukuran sel berkurang dan rerata ukuran sel bertambah. Sel keratinosit menjadi lebih pendek dan besar di kulit yang menua.

Kata kunci: geriatri, mekanisme penuaan kulit, patofisiologi.
\end{abstract}

\section{Skin Aging Mechanism as A Basic Prevention and Treatment of Skin Aging}

\begin{abstract}
Growing geriatric population generates a rise of aging issues. Process of aging develops multiple skin changes that further emerge other related skin problems. Oxidative stress is believed playing vital role related to aging. The aging process in the skin is complex and influenced by intrinsic and extrinsic factors. Intrinsic factors can be in the form of genetics, cell metabolism, and hormonal changes. Meanwhile, for extrinsic factors, such as exposure to ultraviolet, infrared, and carcinogenic agent also have crucial part in aging process. These factors contribute to all layers of the skin. Nowadays, many treatment modalities available to reverse skin aging, however, better understanding on skin aging mechanism, the pathophysiology, and clinical manifestations of aging skin is important to choose the appropriate treatment for patients. In aging, there are physiological changes in permeability, biochemical structures, vascularisation, thermoregulation, irritative response, immunity response, regenerative capability, inflammatory response, neurosensory perception and in genom level. The number of epidermal cells and epidermal overturn rate decline while there is also reduction of sebaseous glands at adnexa which both are accounted for skin xerosis. Decreasing melanocytes can caused gray hair and atypical pigmentation. Hair follicles also show less activity resulting in hair loss. Basal layer cells are downsizing and rise of average cells size are occured. Keratinocyte becomes shorter and bigger in aging skin.
\end{abstract}

Keywords: geriatric, mechanism, skin aging, pathophysiology. 


\section{Pendahuluan}

Kulit adalah organ terluar pada manusia, oleh karena itu perubahan pada kulit dapat dengan mudah diamati. Masalah penuaan kulit meningkat seiring dengan meningkatnya populasi geriatri di dunia. Berbagai perubahan pada kulit terjadi pada populasi ini. Penuaan kulit merupakan proses menurunnya fungsi dan kapasitas kulit secara progresif. Terdapat dua faktor yang berperan pada terjadinya penuaan kulit, yaitu faktor intrinsik dan ekstrinsik. Faktor intrinsik antara lain genetik, metabolisme sel, dan hormonal sedangkan yang termasuk faktor ekstrinsik antara lain radiasi ultraviolet, inframerah, dan karsinogen lingkungan seperti polusi udara. Secara kumulatif faktor tersebut mengubah struktur dan fungsi setiap lapisan kulit secara progresif yang akhirnya mengubah tampilan kulit. Penuaan intrinsik merupakan proses yang tidak terelakan dan pada proses ini kulit mengalami perubahan morfologi dan fisiologi seperti kering, keriput, kendur, dan proses penyembuhan luka menjadi lebih lambat. Pada penuaan ekstrinsik, kulit mengalami kerut dalam, kehilangan elastisitas, dan permukaan kulit menjadi kasar. Berbagai tumor jinak hingga lesi prekanker kulit juga dapat terjadi akibat penuaan ekstrinsik. ${ }^{1}$ Pada makalah ini dibahas proses penuaan kulit secara intrinsik dan ekstrinsik, perubahan struktur kulit pada penuaan, serta berbagai teori penuaan kulit.

\section{Penuaan Intrinsik}

Pada penuaan kulit secara instrinsik, lapisan epidermis menipis sehingga daerah kontak permukaan dermis dan epidermis menipis dan pertukaran nutrisi ke epidermis berkurang. Akibatnya kulit mudah lecet dan robek setelah trauma ringan. Kemampuan proliferasi sel basal semakin menurun. Di lapisan dermis, jumlah sel mast dan fibroblas lebih sedikit dibandingkan di kulit muda dan hal tersebut juga terjadi pada serat kolagen serta serat elastin. ${ }^{1}$

Produksi prokolagen tipe 1 di kulit menua berkurang karena penurunan sinyal TGF- $\beta / S$ mad dan penurunan faktor pertumbuhan jaringan ikat. Terjadi degenerasi di komponen matriks ekstraseluler (elastin, kolagen, fibrilin) dan di oligosakarida yang memengaruhi kemampuan kulit menahan air. ${ }^{2}$ Pada penuaan intrinsik terjadi penipisan kulit, kerutan halus, kulit kering, kulit kendur, dan tumor jinak kulit: keratosis seboroik, cherry angioma. ${ }^{1}$

\section{Penuaan Ekstrinsik}

Pajanan radiasi ultraviolet dari matahari merupakan faktor utama penuaan ekstrinsik sehingga disebut photo aging yang mengacu pada efek pajanan sinar ultraviolet dalam waktu lama. ${ }^{3}$ Pada penuaan ekstrinsik lapisan epidermis menebal, sedangkan pada penuaan intrinsik, lapisan epidermis menipis. Stratum korneum menebal karena kegagalan degradasi korneosit dari desmosom. Diferensiasi keratinosit dari epidermis juga terganggu oleh sinar ultraviolet. Ekspresi kolagen tipe VII dalam keratinosit menurun di area terpajan ultraviolet. Kolagen tersebut merupakan penahan fibril di persimpangan dermis dan epidermis. Berkurangnya produksi kolagen tipe VII berkontribusi terhadap pembentukan keriput karena hubungan dermis dan epidermis melemah. ${ }^{2}$ Pada penuaan ekstrinsik terdapat kerut dalam, kulit longgar, kulit kasar, tipe kulit Fitzpatrick I, II: kerut halus, lesi kulit prakanker (aktinik keratosis) dan kanker kulit, sedangkan pada tipe kulit Fitzpatrick III, IV: kulit hipertrofi, kerut dalam, lentigo. ${ }^{4}$

Elastosis adalah karakteristik penuaan kulit berupa penumpukan jaringan elastin abnormal di lapisan dermis. Sinar ultraviolet meningkatkan ekspresielastinempatkali lipatsehinggamenimbulkan elastosis. Penurunan angiogenesis, penyimpangan ekspresi molekul adhesi, dan kerusakan fungsi vasodilatasi menyebabkan disfungsi edotel sehingga fungsi mikrovaskular menurun. ${ }^{2}$

Merokok merupakan faktor ekstrinsik yang berperan pada penuaan kulit. Studi in vitro menunjukkan bahwa rokok menginduksi MMP-1 dan MMP-3 pada mRNA di fibroblas kulit. Terdapat hubungan jumlah rokok dengan perubahan pigmentasi dan keparahan kerutan. Selain itu perempuan merokok tampak lebih tua dibandingkan nonperokok. Pada pemeriksaan histopatologi terdapat penebalan dan fragmentasi elastin. Terjadi penebalan dan fragmentasi serabut elastin di papila dermis sampai ke retikular dermis. Rokok menyebabkan kulit kering, atrofi, hidrasi stratum korneum menurun, dan percepatan hidroksilasi estradiol sehingga kadar estrogen di kulit menurun., ${ }^{5,6}$

\section{Mekanisme Photodamage di Kulit}

Untuk memahami pencegahan kerusakan kulit akibat pajanan sinar ultraviolet (UV), perlu diketahui mekanisme yang mendasarinya. ${ }^{8}$ Radiasi sinar ultraviolet terdiri atas tiga tipe yaitu:

1. Ultraviolet $C(100-290 \mathrm{~nm})$ yang sebagian besar dihambat oleh lapisan ozon, sehingga efek di kulit cukup kecil

2. Ultraviolet B (290-320 nm) yang dapat menembus sampai lapisan epidermis dan bertanggung jawab atas terjadinya eritema 
akibat terbakar sinar matahari dan mutasi di keratinosit.

3. Ultraviolet $A(320-400 \mathrm{~nm})$, merupakan tipe yang menembus lebih dalam lagi sampai ke dermis dan menyebabkan penuaan kulit serta pigmentasi yang berkepanjangan. ${ }^{5}$

Mekanisme molekular yang mendasari penuaan kulit adalah radiasi sinar UV. Pada saat pajanan, sinar UV berinteraksi dengan kromofor yang sesuai; dapat berupa agen eksogen atau endogen seperti porfirin, flavin, basa DNA, asam amino, dan turunannya seperti asam urokanat. Hasil interaksi berupa kerusakan kromofor secara langsung atau sebagai photosensitizer pembentukan reactive oxygen species (ROS). Peningkatan konsentrasi ROS akan menginisiasi jalur sinyal transduksi melalui aktivasi reseptor permukaan sel termasuk reseptor untuk faktor pertumbuhan epidermal (EGF), interleukin-1 (IL-1), insulin, faktor pertumbuhan keratinosit (KGF), dan faktor tumor nekrosis- $\alpha$ (TNF- $\alpha$ ). Aktivasi reseptor permukaan sel dapat menstimulasi kinase intraselular (p38, c-jun) yang meningkatkan regulasi serta aktivasi faktor transkripsi nuklir dan AP-1. Aktivasi AP-1 menghambat efek transformasi faktor pertumbuhan- $\beta$ (TGF- $\beta$ ) yang menghasilkan gen kolagen. ${ }^{5}$

\section{Teori Penuaan Kulit}

Terdapat berbagai teori mekanisme penuaan kulit, yaitu penuaan seluler, pemendekan telomer, stres oksidatif, DNA mitokondria (mtDNA), hormonal, genetik dll. Stres oksidatif adalah mekanisme yang diduga kuat sebagai penyebab utama penuaan kulit. ${ }^{9}$

\section{Penuaan Seluler}

Teori penuaan seluler menggambarkan hilangnya potensi proliferasi setelah pembelahan sel secara terbatas. Tiap sel memiliki "jam biologis" yang akan memberi sinyal pada akhir replikasi. Konsekuensinya, sel tidak dapat distimulasi untuk memasuki fase $\mathrm{S} 1$ oleh mitogen dan berhenti pada fase G1 karena represi pada gen pengatur pertumbuhan. Pada kultur sel kulit pasien yang mengalami penuaan dini menunjukkan penurunan kemampuan proliferasi sehingga terdapat penumpukan sel yang menua. Hal ini mendukung teori penuaan seluler. ${ }^{7}$

\section{Pemendekan Telomer}

Telomer adalah struktur nukleoprotein tanpa kode di ujung kromosom yang berfungsi sebagai penutup untuk menjaga stabilitas kromosom dengan melindungi kromosom dari degradasi, rekombinasi, dan fusi. Pemendekan telomer berperan pada penuaan sel dan merupakan komponen pada jam mitosis (mitotic clocks). Mekanisme jam (clock mechanism) terjadi karena ketidakmampuan DNA polimerase menyelesaikan replikasi di ujung kromosom linier. Hal tersebut menyebabkan hilangnya sebagian dari ulangan telomer di kromosom (TTAGGG). Telomer memendek secara bertahap pada pembelahan sel saat penuaan sehingga kromosom tidak stabil yang menyebabkan penuaan seluler dan berkurangnya jumlah sel yang membelah. Selain itu, kapasitas proliferasi sel punca epidermal di telomer yang pendek akan terhambat. Pajanan sinar ultraviolet menimbulkan ROS berlebihan sehingga telomer memendek yang mengakibatkan penuaan dan kematian sel. ${ }^{2}$

Pemendekan telomer progresif disebabkan oleh proliferasi seluler. Kapasitas sel selama penuaan dikendalikan oleh telomer dan pemendekan telomer di setiap pembelahan sel berbanding terbalik dengan usia fisiologis individu. Struktur seluler dapat menua dan kehilangan fungsi fisiologis karena telomer telah mencapai ambang batas panjang setelah beberapa proses proliferasi. Pemendekan telomer sebanyak 19,8 base pairs (bp) per tahun, namun Luze et $\mathrm{al}^{10}$ melaporkan pemendekan telomer epidermis terjadi 36 bp per tahun.

\section{Stres Oksidatif}

Stres oksidatif adalah ketidakseimbangan antara ROS yang terbentuk dengan mekanisme pertahanan antioksidan. ROS merupakan senyawa oksigen reaktif dan produk sekunder metabolisme aerobik. Ketidakseimbangan ROS disebabkan oleh produksi ROS yang meningkat dan berkurangnya produksi antioksidan atau keduanya. Stres oksidatif menimbulkan kerusakan oksidatif di berbagai komponen seluler, mengganggu proses komunikasi antar sel, merangsang apoptosis, dan terlibat pada berbagai penyakit yang berhubungan dengan penuaan. ${ }^{2,9}$

Hampir 90\% oksigen dipakai mitokondria untuk menghasilkan energi di tubuh manusia. Pada proses tersebut terbentuk ROS karena pengolahan $\mathrm{O}_{2}$ yang tidak sempurna. ROS adalah radikal bebas yang tidak stabil karena memiliki elektron tidak berpasangan di orbit terluar. Senyawa tersebut menarik elektron dari molekul sekitarnya untuk melengkapi elektron di orbit terluar dan menghasilkan reaksi berantai radikal bebas yang 
sangat berbahaya. Contoh radikal bebas adalah anion superoksida $\left(\mathrm{O}_{2}^{-}\right)$, radikal hidroksil $(-\mathrm{OH})$, dan peroksinitrat (ONOO-). Hidrogen peroksida $\left(\mathrm{H}_{2} \mathrm{O}_{2}\right)$ dan nitrit oksida (NO) bukan radikal bebas, namun tergolong ROS, karena mencetuskan reaksi reduksi oksidasi dan membentuk radikal bebas. ${ }^{9}$

ROS berperan penting dalam homeostasis, respons selular, dan komunikasi antar sel. Efek negatif ROS dicegah dengan antioksidan secara non-enzimatik atau enzimatik, namun kecepatan produksi antioksidan tidak sebanding kecepatan produksi ROS sehingga terjadi penumpukan ROS yang bersifat toksik dan merusak sel. ROS berperan sebagai penyebab penuaan kulit melalui proses oksidasi selular, aktivasi nuklear faktor kappa B, aktivasi mitogen-activated pathway (MAP) kinase, dan stimulasi sitokin proinflamasi. Peningkatan ROS akan merusak protein, lipid, dan DNA sel yang mengakibatkan penuaan kulit. ${ }^{9}$

Penuaan instrinsik menurunkan TGF- $\beta$ dan akumulasi ROS sedangkan penuaan ekstrinsik yang disebabkan pajanan sinar ultraviolet meningkatkan ROS di lapisan dermis. ROS memicu reaksi molekuler berantai sehingga meningkatkan pembentukan AP-1 yang menstimulasi proses transkripsi enzim matrix metalloproteinase (MMP) yang berperan pada degradasi kolagen. ${ }^{9}$

\section{DNA Mitokondria}

Organ utama penghasil ROS dan target utama ROS adalah mitokondria. Lokasi mtDNA yang dekat dengan pembentukan $\mathrm{O}_{2}$ adalah di membran dalam mitokondria yang menyebabkan mtDNA rentan terhadap kerusakan akibat ROS. mtDNA dapat mengalami mutasi yang akan mengganggu proses respirasi dan meningkatkan pembentukan ROS. Setelah itu terdapat kebocoran ROS dari electron transport chain (ETC) yang merusak berbagai komponen sel dan menginduksi mutasi mtDNA sehingga berakibat buruk terhadap sel. ${ }^{9}$

Akumulasi mutasi mtDNA terjadi seiring bertambahnya usia. Kejadian mutasi meningkat di area pengatur replikasi di mtDNA fibroblas geriatri. Peningkatan yang paling bermakna adalah transversi T414G pada individu berusia lebih dari 65 tahun. ROS dapat merusak DNA secara langsung dengan menyerang komponen basa purin (adenin, guanin), basa pirimidin (sitosin, timin), atau gula deoksiribosa. Kerusakan DNA berupa putusnya rantai dan atau modifikasi kimiawi pada susunan basa atau gula deoksiribosa yang mengakibatkan siklus sel terhenti. Selain itu terjadi apoptosis yang ditandai dengan berkurangnya sel keratinosit, sel langerhans, sel mast, dan sel fibroblas pada penuaan kulit. ROS merusak DNA inti, namun kerusakannya lebih rendah daripada mtDNA karena lokasinya lebih dekat dengan tempat produksi ROS. Kemampuan perbaikan mtDNA lebih rendah dibandingkan DNA inti. ${ }^{9}$

\section{Kerusakan DNA}

Pajanan sinar ultraviolet yang terus menerus menyebabkan kerusakan dan mutasi DNA sehingga menimbulkan penuaan kulit atau karsinogenesis. Saat DNA menyerap foton dari UV-B, terjadi penyusunan ulang nukleotida yang merusak DNA. DNA diperbaiki dengan eksisi nukleotida, namun pada defisiensi protein, tetap terjadi kerusakan DNA dan penuaan dini. ${ }^{2}$

\section{Gangguan DNA Repair}

Perbaikan DNA/DNA repair fibroblas di dermis mengalami gangguan pada lansia. Perbaikan DNA dalam sel mampu menghilangkan segmen yang rusak untuk mencegah sel mengalami apoptosis dan melindunginya dari potensi transformasi kanker melalui jalur nucleotide excision repair (NER) atau base excision repair (BER) pathway selama fase G1 dan G2. Respons perbaikan DNA pada orang tua lebih rendah terhadap stres oksidatif akut dibandingkan usia muda. Perbaikan DNA pada subjek lebih tua lebih rendah dibandingkan subjek lebih muda sehingga menyebabkan ketidakstabilan kromosom, perkembangan sel terhenti, apoptosis dan dermatitis kronik yang disebabkan stres oksidatif. ${ }^{10,11}$

\section{Gen dan Mutasi}

Mutasi gen tunggal berkontribusi terhadap inisiasi penuaan dan menginduksi penuaan dini, namun tidak ada gen spesifik yang dapat merusak dan berhubungan dengan penuaan. Penuaan biasanya disebabkan oleh kegagalan pemeliharaan dan mekanisme perbaikan. ${ }^{7,12}$

\section{Penurunan Hormon}

Seiring berjalannya waktu, hormon yang bersirkulasi menurun karena berkurangnya sekresi kelenjar pituitari, adrenal, dan kelenjar di gonad, atau penyakit yang diderita. Faktor pertumbuhan (hormon pertumbuhan dan insulin-like growth factor (IGF-I) serta hormon seks (androgen dan estrogen) menurun signifikan. ${ }^{9}$ Pada penelitian in vitro, sel-sel kulit manusia yang dikultur pada saat hormon disubtitusi menunjukkan perubahan pada sintesis dan metabolisme lipid. Terdapat 
perubahan pada ekspresi gen yang terlibat pada proses biologis seperti perbaikan stabilitas DNA, fungsi mitokondria, stres oksidatif, siklus sel dan apoptosis, serta regulasi transkripsi yang mengindikasikan proses tersebut bergantung pada hormon. . $^{713}$

Hormon IGF-I adalah jalur sinyal penting yang berhubungan dengan penuaan. Kadar IGF-I meningkat dari lahir hingga pubertas, namun menurun secara lambat pada fase dewasa. Penurunan kadar hormon IGF-I berhubungan dengan penurunan progresif hormon pertumbuhan sesuai dengan pertambahan usia. Penurunan kadar IGF-I berhubungan dengan menurunnya tebal epidermis dan kurangnya respons perlindungan terhadap UVB. Hal tersebut menunjukkan penurunan ekspresi IGF-I penting dalam perkembangan kanker kulit non-melanoma yang berhubungan dengan penuaan. ${ }^{7}$

Penurunan hormon pertumbuhan, pituitari multipel dan IGF-I menunjukan tanda-tanda penuaan dini seperti kulit kering, tipis, kerut, obesitas, hiperglikemi, penurunan masa lemak tubuh, osteopenia, penurunan akses vena, hiperkolesterolemia, penyakit kardiovaskular, dan mortalitas dini. Pemberian hormon pertumbuhan pada laki-laki lanjut usia membalik tanda-tanda penuaan, namun terdapat hubungan pemberian faktor pertumbuhan dan peningkatan risiko kanker prostat, paru, usus, dan payudara. Dengan demikian diperlukan penelitian untuk menilai keamanan dan efikasi hormon pertumbuhan pada usia lanjut. ${ }^{14,15}$

\section{Immunosenescence}

Immunosenescence adalah disregulasi imunitas yang berkontribusi terhadap peningkatan kerentanan penyakit pada usia lanjut. Kondisi tersebut merusak kemampuan individu mengembangkan respons imun protektif sehingga mudah menjadi infeksi, kegagalan vaksinasi, keganasan, dan proses autoimun. ${ }^{16,17}$

Pada immunosenescence terjadi perubahan sel-sel penyusun imunitas alamiah dan adaptif yaitu peningkatan berlebihan, penurunan, dan disregulasi respons imun sehingga lebih mudah terinfeksi bakteri atau virus dan respons terhadap vaksin menurun. ${ }^{18}$ Perubahan fisiologis sistem imun terjadi akibat perubahan intrinsik yaitu penurunan perbaikan DNA dan perubahan ekstrinsik terutama pajanan sinar ultraviolet. Kulit yang terpajan sinar matahari secara kronik mengalami perubahan imunologis. ${ }^{19}$

\section{Teori Fenomena Immunosenescence ${ }^{18}$ Teori Autoimun}

Penyakit autoimun disebabkan oleh perbedaan rerata akumulasi sel senescent di sistem imun dan jaringan target disertai akumulasi sel senescent yang heterogen di jaringan/organ. Kedua proses tersebut secara bersama atau terpisah menyebabkan penyakit autoimun. CD5+limfosit B yang memproduksi autoantibodi meningkat pada usia lanjut sehingga terjadi ketidakseimbangan mekanisme kontrol sistem imun terhadap antigen diri sendiri.

\section{Teori imunodefisiensi}

Kemampuan meningkatkan respons imun terhadap antigen baru menurun secara bermakna seiring bertambahnya usia akibat menurunnya sel T naif. Involusi massa timus dan menurunnya cadangan sel $\mathrm{T}$ naif CD8+ memudahkan infeksi dan non-infeksi.

\section{Teori deregulasi}

Menurunnya regulasi toll like receptors (TLRs) dan NOD-like receptors (NLRs) berkontribusi pada berkurangnya pengenalan terhadap patogen atau flora komensal secara efektif.

Karakteristik immunosenescence adalah: involusi massa timus sehingga menurunkan sel $T$ naif, stimulasi antigen terus menerus sehingga perkembangan sel $T$ terganggu dan sel $T$ tua yang teridentifikasi tanpa CD28 sebagai reseptor ko-stimulan, dan inflamasi kronik level rendah "inflammaging" yang dibuktikan oleh peningkatan kadar sitokin inflamasi yaitu TNF- $\alpha$, IL-6 dan protein fase akut. Perubahan tersebut mengubah komposisi seluler dan fungsi seluler dalam membentuk proses pro inflamasi. ${ }^{26}$ Immunosenescence pada usia lanjut mengganggu imunitas alamiah di kulit, mukosa, sel dendritik, sel natural killer (NK), neutrofil, makrofag, sel mikroglia serta imunitas adaptif yaitu limfosit B dan limfosit T. ${ }^{18}$

\section{Perubahan Struktur Kulit pada Penuaan Ketebalan Kulit}

Ketebalan kulit meningkat selama 20 tahun pertama kehidupan dengan jumlah sel yang stabil di tiap lapisan. Dengan bertambahnya usia, kulit dewasa menipis secara progresif. Epidermis yang tidak terpajan matahari menipis sampai $50 \%$ pada usia 30-80 tahun. Penipisan epidermis lebih terlihat di area yang terpajan sinar matahari, seperti wajah, leher, bagian atas dada, dan permukaan ekstensor tangan dan kaki. Ketebalan lapisan epidermis 
berkurang $6,4 \%$ per dekade dan menipisnya epidermis perempuan lebih cepat dibandingkan laki-laki. ${ }^{20}$

Di lapisan dermis, ketebalan, vaskularisasi, dan selularitas juga berkurang dengan faktor yang paling berperan adalah hilangnya kolagen dan elastin. Kecepatan berkurangnya ketebalan lapisan dermis sama pada perempuan dan lakilaki, sedangkan di lapisan hipodermis, bantalan lemak di lapisan berkurang seiring bertambahnya usia. $^{20}$

\section{Epidermis}

Jumlah sel epidermal dan laju pergantian epidermal menurun dengan bertambah usia dan terdapat perubahan karakteristik pada tipe sel di epidermis. Di lapisan basal ukuran sel berkurang dan rerata ukuran sel bertambah. Sel keratinosit menjadi lebih pendek dan besar di kulit yang menua. Korneositlebih besar karena menurunnya pergantian epidermal dan melanosit yang aktif berkurang 8-20\% per dekade sehingga pigmentasi kulit tidak merata di kulit menua. Fungsi dan morfologi sel langherhans seragam, namun jumlahnya berkurang sehingga mengganggu imunitas kulit. Sel langherhans memiliki dendrit lebih sedikit sehingga kemampuan menangkap antigen terganggu. Produksi minyak berkurang, walaupun kelenjar minyak di epidermis tidak berubah. ${ }^{20}$

Stratum korneum merupakan sawar utama terhadap lingkungan dan berperan penting dalam menjaga hidrasi kulit. Strukturnya digambarkan dengan model bricks and mortar, korneosit sebagai batu bata yang tertanam dalam matriks (mortar); terdiri atas seramid, kolesterol, dan asam lemak. Komposisi lipid di kulit tua tidak berubah secara signifikan, namun jumlah kandungan lipid menurun $65 \%$ sehingga mengurangi "mortar" yang mengikat korneosit dan lebih rentan terhadap pertahanan kulit. ${ }^{21,22}$

Di kulit menua, kandungan air terutama di stratum korneum lebih sedikit dibandingkan usia muda. Terjadi perubahan komposisi asam amino dan berkurangnya natural moisturizing factor (NMF) sehingga kapasitas mengikat air di kulit berkurang. Kandungan air di stratum korneum semakin menurun di bawah kadar yang diperlukan untuk deskuamasi efektif. Ketidakmampuan deskuamasi menyebabkan korneosit menumpuk di permukaan kulit sehingga kulit menjadi kasar, terkelupas, dan kering. ${ }^{20}$

Integritas pembatas stratum korneum bergantung pada susunan lemak yang teratur; kandungan lemak di kulit yang menua berkurang $65 \%$. Kadar seramid berkurang di kulit yang menua, terutama seramid 1 linoleat dan seramid 3 ; trigliserida juga berkurang. Kemampuan stratum korneum berregenerasi setelah luka menurun dua kali lebih lambat dan perbaikan barier kulit menurun. ${ }^{20}$

Perbaikan fungsi sawar setelah 24 jam pada usia di atas 80 tahun hanya $15 \%$, sedangkan pada usia muda $50 \%$. Hal tersebut disebabkan pergantian lipid yang menurunkan kadar lipid di badan lamelar yang baru terbentuk. Sintesis lipid dan aktivitas enzim untuk membentuk lipid stratum korneum menurun karena penyimpangan pengatur transkripsi enzim, sinyal autokrin/ parakrin abnormal atau peningkatan $\mathrm{pH}$ stratum korneum yang menghambat aktivitas enzim. ${ }^{24}$ Turn over sel kulit menjadi lebih lambat dan jumlah sel langerhans berkurang. Penurunan jumlah sel Langerhans menurunkan fungsi fagosit makrofag sehingga respons imun di kulit menurun. ${ }^{23}$

Trans epidermal water loss (TEWL) berfungsi menjaga kelembapan kulit, kadarnya rendah pada usia tua dibandingkan pasien usia muda karena berkurangnya kandungan air di kulit menua. Perbaikan TEWL setelah oklusi juga terganggu di kulit menua. ${ }^{22}$ Perubahan struktur di kulit menua yang paling terlihat adalah taut dermo-epidermal yang lebih mendatar karena berkurangnya jumlah dan ukuran papilla dermal. Dengan mendatarnya taut dermo-epidermal maka kulit lebih rentan terhadap gesekan dan gangguan lain. Pendataran taut dermo-epidermal menyebabkan permukaan di antara dermis dan epidermis lebih sempit. Akibatnya komunikasi kedua lapisan berkurang, persediaan nutrisi dan oksigen ke epidermis menghilang, serta terbatasnya proliferasi sel basal; kondisi tersebut memengaruhi penyerapan perkutan. Taut dermoepidermal yang mendatar juga berkontribusi dalam pembentukan kerutan dengan memisahkan dermis dan epidermis. ${ }^{20}$

\section{Dermis}

Kolagen, elastin, dan asam hialuronat adalah komponen matriks ekstraselular yang berperan di dermis. Kadar kolagen berkurang 2\% tiap tahun karena produksi matriks metalloproteinase mendegradasi kolagen seiring bertambahnya usia sehingga merusak integritas struktur dermis. Untuk memelihara keseimbangan sintesis kolagen dan degradasi kolagen oleh enzim, diperlukan ketegangan mekanik dan tekanan di fibroblas dermis yang dihasilkan matriks kolagen sehat. $\mathrm{Di}$ kulit menua, fibroblas akan kolaps karena akumulasi serat kolagen yang terdegradasi sehingga 
menghambat pembentukan matriks kolagen sehat, akibatnya rasio sintesis dan degradasi kolagen menjadi tidak seimbang. ${ }^{20}$

Elemen utama kulit yang memberikan kekuatan adalah kolagen. Kulit mengandung $40 \%$ total kolagen tubuh. Di dermis $97,5 \%$ protein berserat adalah kolagen. Kolagen kulit terdiri atas dua rantai alfa dasar yaitu alfa-1 dan alfa-2, masing-masing terdiri atas $>1000$ residu asam amino. Rantai alfa membentuk triple helix sehingga kolagen sangat kuat. Sekitar $25 \%$ asam amino di kolagen berupa prolin dan hidroksiprolin. ${ }^{24}$

Di organ manusia terdapat 12 jenis molekul kolagen; yang paling banyak dan penyokong utama kulit adalah collagen type I alpha 1 (COL1A1) dan collagen type III alpha 1 (COL3A1). COL1A1 juga terdapat di tulang, tendon, dan jaringan parut, sedangkan COL3A1 di uterus, otot, paru, hati dan arteri besar. Kolagen tipe II, IX, X, XI membentuk tulang rawan sedangkan kolagen tipe IV terdapat di basal lamina sebagai filtration membrane kapiler. Kolagen tipe VII adalah penyokong fibrin di membran basalis DEJ, mukosa oral, dan serviks sedangkan kolagen tipe VII penyokong pembuluh darah. Kolagen tipe $\mathrm{V}, \mathrm{VI}$, dan XII pendukung fungsi mekanis kulit bersama kolagen tipe I dan III. ${ }^{20}$

COL3A1 lebih banyak di kulit usia muda (anakanak) dan berfungsi menjaga kelembutan dan elastisitas kulit. COL1A1 merupakan tipe kolagen predominan di kulit manusia dewasa, kadarnya 80$85 \%$, dengan puncak produksi pada usia sekitar 30 tahun. COL1A1 bertanggung jawab terhadap kekuatan jaringan. Rasio kolagen tipe I dan tipe III di kulit usia muda adalah 6:1. Rasio menurun dengan bertambahnya usia karena kolagen tipe 1 hilang secara selektif. ${ }^{25}$

Biosintesis kolagen bermula dari sel fibroblast, diawali dengan sintesis pre-pro-collagen $\alpha$ (prepro- $\alpha$ ) di ribosom RER dengan vitamin $C$ sebagai kofaktor, kemudian dilepaskan oleh ribosom sebagai prokolagen ke sisterna. Tiga rantai prepro- $\alpha$ menjadi rantai pro- $\alpha$ yang lebih pendek dan menjadi satu triple helix membentuk prokolagen yang dikemas di kompleks golgi, lalu dilepaskan ke permukaan sel oleh vesikel sekretorik prokolagen. Setelah prokolagen disekresi, terbentuk molekul tropokolagen yang lebih pendek dan larut. Molekul tropokolagen secara bertahap mengelompokkan diri dan membentuk kaitan silang antar molekul menjadi serat kolagen tidak larut. ${ }^{25}$

Kolagen didegradasi oleh matrixmetalloprotease (MMP). Jumlah MMP semakin banyak dengan bertambahnya usia dan jika sering terpajan radiasi
UV. Kadar prokolagen 1 di kulit tua menurun $68 \%$ dibandingkan kulit muda dan produksi prokolagen 1 dari fibroblas kulit tua lebih sedikit dibandingkan kulit muda. Pemeriksaan histologi dengan pewarnaan hematoxylin eosin (HE) dan toluidine blue menunjukkan, kulit muda memiliki fiber bundles tebal dengan sedikit rongga antar serat kolagen, sedangkan di kulit tua rongga serta serat tidak beraturan dan tipis. ${ }^{28}$

Di lapisan dermis yang menua, serat kolagen menjadi lebih tebal dan serabut kolagen lebih tidak teratur dibandingkan kulit lebih muda; elastin juga berkurang. Glikosaminoglikan (GAGs) yang merupakan kontributor penting di struktur dan kapasitas menahan air di dermis, berkurang jumlahnya. Selain GAGs, jumlah asam hialuronat dan zat dasar interfibrilar (komponen sehat matriks dermal) juga berkurang. ${ }^{20}$

Hilangnya integritas struktur di dermis menyebabkan hilangnya elastisitas dermis yang lebih cepat terjadi pada perempuan dibandingkan laki-laki. Perubahan akibat penuaan paling banyak di dermis, yaitu menjadi tipis dan ketebalan berkurang hingga $20 \%{ }^{25}$ Respons inflamasi menurun akibat penurunan sintesis dan sekresi sitokin dari keratinosit dan mediator inflamasi, serta penurunan respons endotel. ${ }^{22}$

Kulit manusia kaya serat elastin dengan tingkat kepadatan bervariasi bergantung lokasi. Sebagian besar serat elastin pada usia $>70$ tahun adalah serat elastin abnormal yang mengganggu elastisitas dan ketahanan kulit. ${ }^{24}$ Pada kulit menua, konsentrasi asam hialuronat $(\mathrm{AH})$ di dermis berkurang karena kemampuan ekskresi dan sekresi menurun. Koneksi yang dibentuk $\mathrm{AH}$ antara kolagen dan elastin serta kemampuan retensi air oleh $\mathrm{AH}$ juga berkurang, sehingga menimbulkan kerut, elastisitas kulit dan ketebalan kulit berkurang, serta melemahnya fungsi kulit sebagai jaringan penunjang. Serabut elastin di dermis mengalami perubahan struktur dan fungsi, sehingga deposisi GAG di dermis mencegah retensi air yang optimal. ${ }^{23}$

Karakteristik penting penuaan kulit adalah menurunnya aliran darah. Diameter venula berkurang $35 \%$ terutama di dermis papilaris dan loop kapiler vertikal berkurang. Hal itu menyebabkan aliran darah berkurang, pertukaran nutrisi minimal, termoregulasi terhambat, suhu permukaan kulit menurun, dan warna kulit pucat. Heat stroke atau hipotermia lebih sering terjadi karena menurunnya aktivitas vasokonstriksi arteriol dermis dan hilangnya lemak subkutan. ${ }^{23}$ 


\section{Hipodermis}

Walaupun proporsi lemak subkutan bertambah sampai usia 70 tahun, volume lemak subkutan secara keseluruhan berkurang dengan bertambahnya usia. Distribusi lemak berkurang di wajah, tangan, dan kaki, namun meningkat di area paha, pinggang dan perut. ${ }^{20}$

\section{Perubahan di Adneksa}

Kulit kering dan mudah pecah terjadi karena penurunan jumlah kelenjar sebasea. Penurunan produksi keringat meningkatkan heat stroke pada orang tua. Penurunan jumlah melanosit menyebabkan warna rambut menjadi abu-abu keputihan dan muncul pigmentasi atipik di kulit. Folikel rambut kurang aktif sehingga meningkatkan kerontokan dan kebotakan. ${ }^{27}$

\section{Perubahan Fisiologi pada Kulit Menua}

Perubahan fisiologi pada penuaan kulit meliputi perubahan permeabilitas, biokimia, vaskularisasi, termoregulasi, respons terhadap iritan, respons imunitas, kapasitas regenerasi, respons terhadap cedera, persepsi neurosensori, dan pada tingkat genom. ${ }^{20}$

\section{Permeabilitas}

Penetrasi dan transit suatu zat melalui kulit melibatkan beberapa tahap absorbsi ke stratum korneum, difusi melalui stratum korneum, epidermis, papila dermis, dan pemindahan oleh mikrosirkulasi. Tahap pertama dan kedua bergantung pada integritas dan hidrasi stratum korneum, sedangkan tahap ketiga bergantung pada integritas mikrosirkulasi. Pemberian obat secara transdermal mulai diperhatikan karena efek sampingnya minimal dan kepatuhan obat lebih baik. Pada lansia, penyerapan obat topikal lebih lambat dibandingkan individu yang lebih muda. Pada penelitian in vitro didapatkan tingginya permeabilitas kulit menua pada pemakaian testosteron, namun pada penelitian in vivo absorbsi hidrokortison dan asam benzoat lebih sedikit di kulit menua dibandingkan di kulit usia muda. ${ }^{20,28}$

Penetrasi epidermal suatu zat bergantung pada hidrofobisitas yang berhubungan dengan lemak di kulit sehingga senyawa hidrofobik lebih mudah menembus area tubuh yang memiliki persentase lipid kulit yang tinggi. Di area wajah, kadar lipid kulit $12-15 \%$, senyawa hidrofobik lebih mudah berpenetrasi dibandingkan senyawa hidrofilik. Di telapak kaki, persentase lipid kulit adalah 1-2\%, senyawa hidrofilik lebih mudah berpenetrasi dibandingkan senyawa hidrofobik. ${ }^{20}$

\section{Biokimia}

Sintesis vitamin D melambat karena kurangnya senyawa prekursor 7-dehidrokolesterol di lapisan dermis dan epidermis sehingga membatasi pembentukan vitamin D. ${ }^{20} \mathrm{Di}$ permukaan kulit normal orang dewasa rerata $\mathrm{pH}$ adalah 5.5. Keasaman di kulit menghambat kolonisasi bakteri dan berkontribusi di sawar kelembapan kulit karena asam amino, garam, dan senyawa lain di mantel asam menyerap air. $\mathrm{pH}$ di kulit relatif konstan sejak usia dini hingga umur 70 , namun saat usia $>70$, $\mathrm{pH}$ meningkat signifikan terutama di ekstremitas bawah karena sirkulasi terganggu. ${ }^{20}$

\section{Vaskularisasi dan Termoregulasi}

Pola aliran darah melalui kapiler tidak berubah pada satu individu, namun aliran darah maksimum menghilang karena hilangnya pleksus kapiler di kulit menua. Pada penelitian potong lintang, didapatkan bahwa penuaan kulit akibat sinar ultraviolet menunjukkan $35 \%$ penurunan vaskularisasi di dermis. Selain itu, didapatkan penurunan aliran darah, hilangnya pertukaran nutrisi, disfungsi termoregulasi, penurunan temperatur permukaan kulit, dan kulit semakin pucat. Pada pasien geriatri temperatur kulit lebih rendah dan pasien lebih rentan terhadap hipotermia serta heat stroke karena kerusakan kelenjar keringat ekrin, kurangnya vasodilatasi atauvasokonstriksi arteriol dermis, dan hilangnya lemak subkutan yang menghambat termoregulasi. ${ }^{20}$

\section{Respons terhadap Iritan}

Respons inflamasi terhadap agen eksogen menurun pada usia $>70$ tahun yaitu menjadi lebih lambat, lebih tidak intens, dan beberapa tanda klinis kerusakan kulit tidak muncul. Diagnosis penyakit kulit pada pasien geriatri menjadi lebih sulit karena manifestasi iritasi di kulit kurang jelas. Pajanan terhadap bahan kimia seperti sabun mandi, minyak tanah, dimetil sulfida, asam nikotinat, kloroformmetanol, dan asam laktat pada saat patch testing menunjukkan eritema dan sedikit vesikel pustul. Pada perubahan TEWL setelah pajanan sodium lauryl sulfate (SLS) di kulit, reaksi iritasi lebih lambat dan jarang pada individu menopause. Iritan kimia menghasilkan efek berbeda di kulit menua karena tiap iritan mempunyai mekanisme berbeda. SLS dan asam nonanoat menganggu metabolisme dan diferensiasi keratinosit sedangkan ditranol menginduksi inflamasi di keratinosit lapisan epidermis. ${ }^{20}$ 


\section{Kemampuan Regenerasi dan Respons terhadap Cedera}

Setiap hari terjadi deskuamasi di satu lapisan korneosit di kulit sehat agar seluruh stratum korneum terganti setiap dua minggu. Namun, di stratum korneum kulit menua pergantian stratum korneum dua kali lebih lambat dibandingkan kulit muda. Proses penyembuhan luka lebih lambat dengan bertambahnya usia. Di luka yang berukuran 40 $\mathrm{cm}^{2}$ proses penyembuhan luka pada usia 20 tahun berlangsung 40 hari, sedangkan pada usia $>80$ tahun memerlukan waktu dua kali lipat (76 hari). Risiko pembukaan luka pasca-operasi meningkat $600 \%$ pada usia pertengahan 80 tahun dibandingkan usia pertengahan 30 tahun. Proses perbaikan seperti collagen remodelling, proliferasi seluler, dan metabolisme luka akan tertunda pada usia lanjut. ${ }^{20}$

Pergantian stratum korneum menjadi lebih lama, yang biasanya 20 hari pada di kulit menua menjadi 30 hari. Re-epitelisasi di stratum korneum setelah kulit melepuh juga berkurang. Produksi mRNA dan protein IL-1 juga berkurang sehingga proses penyembuhan lambat. ${ }^{20}$

\section{Persepsi Neurosensori}

Pasien usia lanjut sering mengeluh gatal di kulit, namun persepsi nyeri menurun seiring bertambahnya usia. Oleh karena itu, risiko cedera jaringan yang biasanya bermanifestasi nyeri, eritema, dan edema, muncul lebih lambat. ${ }^{20}$

\section{Perubahan pada Tingkat Genom}

Penuaan membawa perubahan pada fenotipe tanpa mengubah urutan genetik yang sudah dikodekan pada tiap DNA individu. Kerusakan kulit umumnya berasal dari perubahan DNA yang tidak memengaruhi urutan genetic yang disebut perubahan epigenetik. Perubahan terdiri atas modifikasi DNA dan translasi menjadi protein dengan modifikasi kolagen terhadap histon dan metilasi residu sitosin di DNA yang mengubah fenotipe. DNA pada penuaan menunjukkan hipermetilasi spesifik di jaringan dan menyebabkan perubahan fenotipe. ${ }^{20}$

\section{Perubahan di Lapisan Kulit}

Di lapisan kulit perubahan berupa penurunan jumlah melanosit dan sel langerhans epidermis serta perubahan di taut dermo-epidermal sehingga menurunkan pertukaran nutrisi, hilangnya volume dermis, berkurangnya suplai darah, serta penurunan aktivitas tirosinase. ${ }^{6}$ Di lapisan dermis, kolagen, elastin, dan asam hialuronat mengalami perubahan struktural dan fungsional. Kerusakan komponen tersebut terakumulasi seiring berjalannya waktu dan terjadi penurunan fungsi. Penuaan kulit intrinsik ditandai dengan atrofi dermis, kurangnya serat kolagen, elastin, dan asam hialuronat yang mengakibatkan pembentukan kerut dan garis-garis yang diperberat gaya gravitasi, serta hilangnya lemak subkutan. ${ }^{6}$ Penuaan ekstrinsik ditandai dengan degradasi, perubahan serat kolagen dan akumulasi elastin yang berantakan (elastosis). Metaloproteinase dapat diinduksi oleh UVA dan UVB dengan aktivitas proteolitik yang menghasilkan degradasi serat kolagen dan elastin. Manifestasi klinik penuaan kulit ekstrinsik adalah peningkatan pembentukan keriput, kulit rapuh, perubahan pigmentasi kulit, dan permukaan kasar. ${ }^{6}$

\section{Penutup}

Penuaan kulit merupakan proses yang kompleks; terdiri atas faktor intrinsik dan faktor ekstrinsik yang saling berhubungan. Perubahan di kulit bermanifestasi sebagai kelainan yang dapat diamati dan berbagai teori serta sudut pandang berbeda dalam mekanisme penuaan kulit. Oleh karena itu perlu dipahami patofisiologi penuaan kulit untuk menentukan tata laksana yang tepat dalam mencegah dan mengobati penuaan kulit.

\section{Daftar Pustaka}

1. Kerns ML, Chien AL, Kang S. Skin aging. Dalam: Kang S, Amagai M, Bruckner AL, EnkAH, Margolis DJ, McMichael AJ, et al, editor. Fitzpatrick's dermatology. Edisi ke-9. New York: McGraw Hill; 2019. h.1779-91.

2. Zhang S, Duan E. Fighting against skin aging: the way from bench to bedside. Cell Transplant. 2018;27:729-38. doi: 10.1177/0963689717725755

3. Chen S, He Z, Xu J. Application of adipose-derived stem cells in photoaging: basic science and literature revies. Stem Cell Res Ther. 2020;11:491. doi: 10.1186/s13287-020-01994-z

4. Kim M, Park HJ. Molecular mechanisms of skin aging and rejuvenation. IntechOpen; 2016.

5. Damayanti. Penuaan kulit dan perawatan kulit dasar pada usia lanjut. Berkala IImu Kesehatan Kulit dan Kelamin. 2017;29:73-80.

6. Ramos-e-Silva M, da Silva CSC. Elderly skin and its rejuvenation: products and procedures for the aging skin. J Cosmet Dermatol. 2007;6:40-50. doi: 10.1111/j.1473-2165.2007.00289.x

7. Makrantonaki E, Zouboulis CC. Pathomechanisms of endogenously aged skin. Textbook of aging skin. Edisi ke-2. Berlin: Springer; 2017.h.111-8.

8. Luze H, Nischwitz SP, Zalaudek I, Mullegger R, Kamolz LP. DNA repair enzymes in sunscreens and their impact on photoageing - a systematic review. Photodermatol Photoimmunol Photomed. 2020;36: 424-32. doi: 10.1111/phpp.12597 
9. Djuanda SRS, Novianto E, Boediardja SA, Jusman SWA. Peran stres oksidatif pada penuaan kulit secata intrinsik. MDVI. 2012;39:127-33.

10. Wagner KH, Cameron-Smith D, Wessner B, Franzke B. Biomarkers of aging: from function to molecular biology. Nutrients. 2016;8:338. doi: 10.3390/ nu8060338

11. Yarosh DB, Rosenthal A, Moy R. Six critical questions for DNA repair enzymes in skincare products: a review in dialog. Clin Cosmet Investig Dermatol. 2019;12:617-24. doi: 10.2147/CCID.S220741

12. Iliadi KG, Knight D, Boulianne GL. Healthy aging insights from Drosophila. Front Physiol. 2012;3:106. doi: 10.3389/fphys.2012.00106

13. Mukherjee S, Mitra R, Maitra A, Gupta S, Kumaran $S$, Chakrabortty A, et al. Sebum and hydration levels in specific regions of human face significantly predict the nature and diversity of facial skin microbiome. Sci Rep. 2016;6:36062. doi: 10.1038/srep36062

14. van der Spoel E, Jansen SW, Akintola AA, Ballieux BE, Cobbaert CM, Slagboom PE, et al. Growth hormone secretion is diminished and tightly controlled in humans enriched for familial longevity. Aging Cell. 2016;15:1126-31. doi: 10.1111/acel.12519

15. He X, Barkan AL. Growth hormone therapy in adults with growth hormone deficiency: a critical assessment of the literature. Pituitary. 2020;23:294306. doi: 10.1007/s11102-020-01031-5

16. Whaley MM, Lane J, Carruthers C, Walker L, Barber DL. The aging process. Occupational therapy with elders. Edisi ke-4. Missouri: Elsevier; 2017.h.30-40.

17. Dewan SK, Zheng SB, Xia SJ, Bill K. Senescent remodeling of the immune system and its contribution to the predisposition of the elderly to infections. Chin Med J. 2012 ;125:3325-31.

18. Fuentes $\mathrm{E}$, Fuentes $\mathrm{M}$, Alarcón $\mathrm{M}$, Palomo I. Immune system dysfunction in the elderly. An Acad Bras Cienc. 2017;89:285-99. doi: 10.1590/00013765201720160487
19. Jafferany M, Huynh TV, Silverman MA, Zaidi Z. Geriatric dermatoses: a clinical review of skin diseases in an aging population. Int $\mathrm{J}$ Dermatol. 2012;51:509-22. doi: 10.1111/j.13654632.2011.05311.x

20. Farage MA, Miller KW, Maibach HI. Degenerative changes in aging skin. Textbook of aging skin. Edisi ke-2. Berlin: Springer; 2017.h.16-27.

21. Tobin DJ. Introduction to skin aging. J Tissue Viability. 2017;26:37-46. doi: 10.1016/j.jtv.2016.03.002

22. Farage MA, Miller KW, Elsner $P$, Maibach $\mathrm{HI}$. Characteristics of the aging skin. Advances in wound care. 2013;2(1).5-10. doi: 10.1089/ wound.2011.0356

23. Kohl E, Steinbauer J, Landthaler M, Szeimies RM. Skin ageing. J Eur Acad Dermatol Venereol. 2011;25:873-84. doi: 10.1111/j.14683083.2010.03963.x

24. Soerensen M. Genetic variation and human longevity. Dan Med J. 2012;59:B4454.

25. Cheng W, Yan-hua R, Fang-gang N, Guo-an Z. The content and ratio of type I and III collagen in skin differ with age and injury. Afr $\mathrm{J}$ of Biotechnol. 2011;10:2524-9.

26. Li Y, Lei D, Swindell WR, Xia W, Weng S, Fu J, et al. Age-associated increase in skin fibroblast-derived prostaglandin e2 contributes to reduced collagen levels in elderly human skin. J Invest Dermatol. 2015;135:2181-8. doi: 10.1038/jid.2015.157

27. Morrow A, Lechler T. Studying cell biology in the skin. Mol Biol Cell. 2015;26:4183-6. doi: 10.1091/ mbc.E15-04-0246

28. Russell-Goldman E, Murphy GF. The pathobiology of skin aging: new insights into an old dilemma. Am J Pathol. 2020;190:1356-69. doi: 10.1016/j. ajpath.2020.03.007 